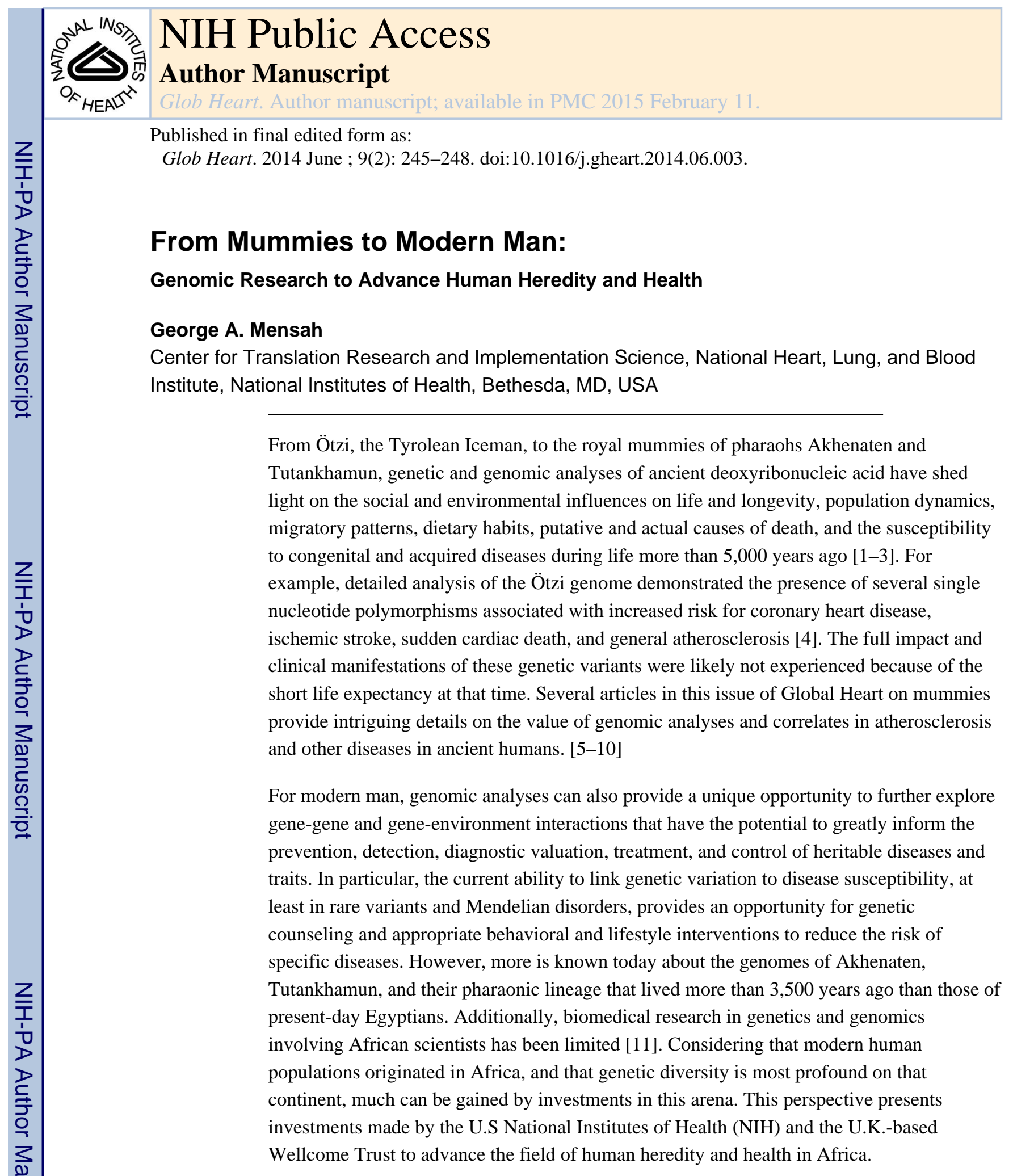

(C) 2014 Published by Elsevier Ltd. on behalf of World Heart Federation (Geneva).

This is an open access article under the CC BY-NC-ND license (http://creativecommons.org/licenses/by-nc-nd/3.0/).

Correspondence: G. Mensah (George.Mensah@nih.gov).

Dr. Mensah reports no relationships that could be construed as a conflict of interest.

The views expressed in this article are those of the author and do not necessarily represent the views of the National Heart, Lung, and Blood Institute, National Institutes of Health, or the U.S. Department of Health and Human Services. 


\section{The H3Africa Project}

Recognizing the limited investment and engagement of Africa and African biomedical research scientists in human genetics and genomics, the NIH and the Wellcome Trust, in partnership with the African Society of Human Genetics established the H3Africa (Human Heredity and Health in Africa) Consortium with the goal of identifying the major scientific, ethical, and practical issues in the development of a large-scale genomics research program in Africa. As noted in the H3Africa Working Group white paper, "the model proposed for H3Africa seeks to position Africa not only as a vital resource for genetic and genomic data collection but also as the recognized scientific hub for the initiation and full implementation of modern genetic and genomics research in African populations" [11].

Specific recommendations were made for infrastructure development to include fully functional biorepositories; regional centers of excellence that will house modern genotyping/ sequencing and phenotyping laboratories; clinical centers that will collect demographic, epidemiologic, and clinical data on all H3Africa participants; and a continent-wide bioinformatics network that will provide the necessary foundation for the large-scale genomic datasets [11]. Other recommendations included emphasis on education and training of African scientists in multiple disciplines, including genomics (high-throughput technologies); genetics; epidemiology; bioinformatics; statistical genetics; and ethical, legal, and social issues.

Recognizing the huge burden of infectious diseases in Africa, the initial focus of H3Africa included emphasis on tuberculosis, human African trypanosomiasis, and cancer due to infectious agents. Noncommunicable diseases of interest included sickle cell disease, rheumatic heart disease, hypertension, stroke, type 2 diabetes mellitus, and cancer. In addition, pharmacogenomics and the development of new and innovative approaches for the prevention, diagnosis, evaluation, and treatment of these diseases were highlighted. A key principle was that the choice and focus of research topic and the specific methodological approaches should reflect the interests and expertise of the African investigators who are to be the project leaders.

As stated in the white paper, the vision of the H3Africa Consortium "is to create and support a pan-continental network of laboratories that will be equipped to apply leading-edge research to the study of the complex interplay between environmental and genetic factors which determines disease susceptibility and drug responses in African populations" [11]. Today, there are 21 collaborating investigator teams funded at approximately US\$76 million; 18 of them are funded by the NIH and the remaining 3 are funded by the Wellcome Trust. As shown in Table 1, the work of the collaborating teams include developing an Africa-based bioinformatics network for H3Africa; several biorepositories; an ethical, legal, and social issues project; and tackling research themes that span the spectrum from pharmacogenomics in multiple drug-resistant tuberculosis to the genomics of schizophrenia. The Wellcome Truste funded projects include 3 collaborative networks addressing the following: 1) the genetics of rheumatic heart disease (RHDGen); 2) an integrated approach to the identification of genetic determinants of susceptibility to trypanosomiasis (TrypanoGEN); and 3) an investigation of the etiology of type 2 diabetes in sub-Saharan 
Africa. The H3Africa Consortium members also collaborate on several working groups that deliberate, plan, and help harmonize H3Africa research activities. The most recently constituted working group addresses cardiovascular diseases.

\section{H3Africa Cardiovascular Diseases Workshop}

On May 30, 2014, in conjunction with the fourth annual meeting of the H3Africa Consortium (http://www.h3africa.org/component/content/article/8-events/156-fourthh3africa-consortium-meeting), the Cardiovascular Working Group held an inaugural workshop in Cape Town, South Africa. The primary workshop objectives were to enhance understanding of the genetic underpinnings of the common major cardiovascular diseases in Africa and strengthen collaborations among the H3Africa investigative teams and other researchers using novel genomic and epidemiological tools to contribute to reducing the burden of cardiovascular disease on the continent [12]. Other important goals of the workshop included strengthening synergistic collaboration among H3Africa teams who are currently exploring cardiovascular diseases and their risk factors using novel genomic and epidemiological tools and facilitating an appreciation of the pathophysiological interrelationships between car-diometabolic diseases and certain infectious diseases common in Africa [12]. This is an exciting development for global health in general and for cardiovascular health in Africa in particular. As was poignantly summarized in a recent commentary, the H3Africa consortium "ignites hope, as it will enhance the capacity of African researchers for cutting-edge research" and it may represent "the long-awaited tipping point for a revolution in bioinformatics, genomics and health research in Africa" [13].

Although each of the above developments represents good news in genomics and biomedical research, the H3Africa Consortium members recognize that, by themselves, their efforts in this endeavor will not be enough [14]. The time has now come for the global health community to leverage and build on the foundational investments made by the NIH and the Wellcome Trust in order to address compelling scientific questions about human heredity and health that a large-scale, genomics-focused, population-based research program in Africa is most suited to tackle. For global cardiovascular health research, this also represents an exciting opportunity!

\section{Acknowledgments}

I am grateful to my NIH colleagues Dr. Charles Rotimi (National Human Genome Research Institute and H3Africa Consortium), Dr. Daniel Levy (National Heart, Lung, and Blood Institute), and Dr. Emmanuel Peprah (Eunice Kennedy Shriver National Institute of Child Health and Human Development), who reviewed and provided constructive comments on an earlier version of this manuscript.

\section{References}

1. Keller A, Graefen A, Ball M, et al. New insights into the Tyrolean Iceman's origin and phenotype as inferred by whole-genome sequencing. Nat Commun. 2012; 3:698. [PubMed: 22426219]

2. Khairat R, Ball M, Chang CC, et al. First insights into the metagenome of Egyptian mummies using next-generation sequencing. J Appl Genet. 2013; 54:309-25. [PubMed: 23553074]

3. Hawass Z, Gad YZ, Ismail S, et al. Ancestry and pathology in King Tutankhamun's family. JAMA. 2010; 303:638-47. [PubMed: 20159872] 
4. Zink A, Wann LS, Thompson RC, et al. Genomic correlates of atherosclerosis in ancient humans. Glob Heart. 2014; 9:203-9. [PubMed: 25667090]

5. Thompson RC, Allam AH, Zink A, et al. Computed tomographic evidence of atherosclerosis in the mummified remains of humans from around the world. Glob Heart. 2014; 9:187-96. [PubMed: 25667088]

6. Allam AH, Mandour Ali MA, Wann LS, et al. Atherosclerosis in ancient and modern Egyptians: the Horus study. Glob Heart. 2014; 9:197-202. [PubMed: 25667089]

7. Miyamoto MI, Djabali K, Gordon LB. Atherosclerosis in ancient humans, accelerated aging syndromes and normal aging: is lamin A protein a common link? Glob Heart. 2014; 9:211-8. [PubMed: 25667091]

8. Sutherland ML, Cox SL, Lombardi GP, et al. Funerary artifacts, social status, and atherosclerosis in ancient Peruvian mummy bundles. Glob Heart. 2014; 9:219-28. [PubMed: 25667092]

9. Thomas GS, Wann LS, Allam AH, et al. Why did ancient people have atherosclerosis? From autopsies to computed tomography to potential causes. Glob Heart. 2014; 9:229-37. [PubMed: 25667093]

10. Wann LS, Thompson RC, Allam AH, et al. Atherosclerosis: a longue durée approach. Glob Heart. 2014; 9:239-44. [PubMed: 25667094]

11. The H3Africa Working Group. [Accessed June 10, 2014] Harnessing Genomic Technologies Towards Improving Health in Africa: Opportunities and Challenges. White paper. Jan. 2011 Available at: URL: http://h3africa.org/images/PDF/h3africa_whitepaper.pdf

12. Owolabi MO, Mensah GA, Kimmel PL, et al. for the H3Africa Consortium. Understanding the rise in cardiovascular diseases in Africa: harmonising H3Africa genomic epidemiological teams and tools. Cardiovasc J Afr. 2014; 25:1-4.

13. Adoga MP, Fatumo SA, Agwale SM. H3Africa: a tipping point for a revolution in bioinformatics, genomics and health research in Africa. Source Code Biol Med. 2014; 9:10. [PubMed: 24829612]

14. H3Africa Consortium. Research capacity. Enabling the genomic revolution in Africa. Science. 2014; 344:1346-8. [PubMed: 24948725] 
Table 1

H3Africa Consortium's collaborating centers and research projects funded by the National Institutes of Health and the Wellcome Trust

\begin{tabular}{|c|c|c|c|c|}
\hline Theme & Funding Source & Research Focus & Principal Investigator & Affiliation \\
\hline Biorepository & $\mathrm{NIH}$ & $\begin{array}{l}\text { Development of H3Africa } \\
\text { biorepositories to facilitate } \\
\text { studies on biodiversity, } \\
\text { disease, and } \\
\text { pharmacogenomics of } \\
\text { African populations }\end{array}$ & Akin Abayomi & $\begin{array}{l}\text { Stellenbosch } \\
\text { University, } \\
\text { Stellenbosch, South } \\
\text { Africa }\end{array}$ \\
\hline Biorepository & $\mathrm{NIH}$ & $\begin{array}{l}\text { H3 African Biorepository (I- } \\
\text { HAB) Initiative }\end{array}$ & Alash'le G Abimiku & $\begin{array}{l}\text { Institute of Human } \\
\text { Virology, Nigeria, } \\
\text { Abuja }\end{array}$ \\
\hline Biorepository (pilot project) & $\mathrm{NIH}$ & $\begin{array}{l}\text { Establishment of an } \\
\text { H3Africa Biorepository at } \\
\text { Clinical Laboratory Services } \\
\text { (pilot project) }\end{array}$ & Ute Jentsch & $\begin{array}{l}\text { University of the } \\
\text { Witwatersrand, } \\
\text { Johannesburg, South } \\
\text { Africa }\end{array}$ \\
\hline $\begin{array}{l}\text { Integrated biorepository (pilot } \\
\text { project) }\end{array}$ & $\mathrm{NIH}$ & $\begin{array}{l}\text { Integrated Biorepository of } \\
\text { H3Africa Uganda (pilot } \\
\text { project) }\end{array}$ & Moses Joloba & $\begin{array}{l}\text { Makerere University } \\
\text { College of Health } \\
\text { Sciences, Kampala, } \\
\text { Uganda }\end{array}$ \\
\hline Bioinformatics & $\mathrm{NIH}$ & $\begin{array}{l}\text { H3ABioNet: A Sustainable } \\
\text { African Bioinformatics }\end{array}$ & Nicola Mulder & $\begin{array}{l}\text { University of Cape } \\
\text { Town, South Africa }\end{array}$ \\
\hline Cardiometabolic disease & $\mathrm{NIH}$ & $\begin{array}{l}\text { Genomic and environmental } \\
\text { risk factors for } \\
\text { cardiometabolic disease in } \\
\text { Africans }\end{array}$ & Michele Ramsay & $\begin{array}{l}\text { University of the } \\
\text { Witwatersrand and } \\
\text { NHLS, Johannesburg }\end{array}$ \\
\hline Kidney disease & $\mathrm{NIH}$ & $\begin{array}{l}\text { H3Africa Kidney Disease } \\
\text { Research Network }\end{array}$ & $\begin{array}{l}\text { Dwomoa Adu Akinlolu } \\
\text { Ojo }\end{array}$ & $\begin{array}{l}\text { University of Ghana } \\
\text { Medical School, } \\
\text { Accra; University of } \\
\text { Michigan, Ann Arbor }\end{array}$ \\
\hline Schizophrenia & $\mathrm{NIH}$ & $\begin{array}{l}\text { The Genomics of } \\
\text { Schizophrenia in the South } \\
\text { African Xhosa People }\end{array}$ & $\begin{array}{l}\text { Dan Stein; Ezra Susser } \\
\text { Mary-Claire King }\end{array}$ & $\begin{array}{l}\text { University of Cape } \\
\text { Town, South Africa; } \\
\text { Columbia University, } \\
\text { New York; University } \\
\text { of Washington, Seattle }\end{array}$ \\
\hline Cervical cancer & $\mathrm{NIH}$ & $\begin{array}{l}\text { African Collaborative Center } \\
\text { for Microbiome and } \\
\text { Genomics Research }\end{array}$ & Clement Adebamowo & $\begin{array}{l}\text { University College } \\
\text { Hospital, Ibadan, } \\
\text { Nigeria }\end{array}$ \\
\hline Stroke & $\mathrm{NIH}$ & $\begin{array}{l}\text { Stroke Investigative } \\
\text { Research and Educational } \\
\text { Network }\end{array}$ & Mayowa Owolabi & $\begin{array}{l}\text { University of Ibadan, } \\
\text { Nigeria }\end{array}$ \\
\hline Pharmacokinetics & $\mathrm{NIH}$ & $\begin{array}{l}\text { Contribution of genetic } \\
\text { variation to pharmacokinetic } \\
\text { variability and toxicity in } \\
\text { patients undergoing } \\
\text { multidrug tuberculosis } \\
\text { treatment in Sub-Saharan } \\
\text { Africa }\end{array}$ & Dissou Affolabi & $\begin{array}{l}\text { National Hospital } \\
\text { forTuberculosis and } \\
\text { Pulmonary Diseases, } \\
\text { Cotonou, Benin }\end{array}$ \\
\hline $\begin{array}{l}\text { HIV and HIV-TB infections in } \\
\text { Sub-Saharan African children }\end{array}$ & $\mathrm{NIH}$ & $\begin{array}{l}\text { The Collaborative African } \\
\text { Genomics Network } \\
\text { (CAfGEN) will probe host } \\
\text { factors in the progression of } \\
\text { HIV and HIV-TB infection } \\
\text { in Sub-Saharan African } \\
\text { children }\end{array}$ & $\begin{array}{l}\text { Gabriel Anabwani, } \\
\text { Kekitiinwa Rukyalekere, } \\
\text { Moses Joloba, Oathokwa } \\
\text { Nkomazana, Sununguko } \\
\text { W. Mpoloka, Graeme } \\
\text { Mardon }\end{array}$ & $\begin{array}{l}\text { Botswana e Baylor } \\
\text { Children's Clinical } \\
\text { Centre of Excellence, } \\
\text { Botswana; Baylor } \\
\text { College of Medicine } \\
\text { Children's Foundation, } \\
\text { Uganda; Baylor } \\
\text { College of Medicine, } \\
\text { USA; Makerere } \\
\text { University, Uganda, } \\
\text { and University of } \\
\text { Botswana, Botswana }\end{array}$ \\
\hline
\end{tabular}




\begin{tabular}{|c|c|c|c|c|}
\hline Theme & Funding Source & Research Focus & Principal Investigator & Affiliation \\
\hline Tuberculosis & $\mathrm{NIH}$ & $\begin{array}{l}\text { Systems Biology for } \\
\text { Molecular Analysis of } \\
\text { Tuberculosis }\end{array}$ & Gobena Ameni & $\begin{array}{l}\text { Addis Ababa } \\
\text { University, Ethiopia }\end{array}$ \\
\hline Febrile illnesses & $\mathrm{NIH}$ & $\begin{array}{l}\text { Host and Microbial Genetic } \\
\text { Determinants of Febrile } \\
\text { Illness in West Africa }\end{array}$ & Christian Happi & $\begin{array}{l}\text { Redeemer's University, } \\
\text { Redemption City, } \\
\text { Nigeria }\end{array}$ \\
\hline Hereditary neurological disorders & $\mathrm{NIH}$ & $\begin{array}{l}\text { Clinical and Genetic Studies } \\
\text { of Hereditary Neurological } \\
\text { Disorders in Mali }\end{array}$ & Guida Landouré & $\begin{array}{l}\text { University Hospital } \\
\text { Center du Point G, } \\
\text { Bamako, Mali }\end{array}$ \\
\hline Infectious respiratory diseases & $\mathrm{NIH}$ & $\begin{array}{l}\text { The Nasopharyngeal } \\
\text { Microbiome and Respiratory } \\
\text { Disease in African Children }\end{array}$ & Mark Nicol Heather Zar & $\begin{array}{l}\text { University of Cape } \\
\text { Town, South Africa }\end{array}$ \\
\hline $\begin{array}{l}\text { Ethical, legal, and social } \\
\text { implications }\end{array}$ & $\mathrm{NIH}$ & $\begin{array}{l}\text { Exploring Perspectives on } \\
\text { Genomics and Sickle Cell } \\
\text { Public Health Intervention }\end{array}$ & Ambroise Wonkam & $\begin{array}{l}\text { University of Cape } \\
\text { Town, South Africa }\end{array}$ \\
\hline Trypanosomiasis & $\mathrm{NIH}$ & $\begin{array}{l}\text { Reprogramming of the } \\
\text { Trypanosoma brucei } \\
\text { epigenome during human } \\
\text { infection: opportunities for } \\
\text { new therapies }\end{array}$ & Hugh Patterton & $\begin{array}{l}\text { University of the Free } \\
\text { State, Bloemfontein, } \\
\text { South Africa }\end{array}$ \\
\hline Trypanosomiasis & WT & $\begin{array}{l}\text { TrypanoGEN: an integrated } \\
\text { approach to the identification } \\
\text { of genetic determinants of } \\
\text { susceptibility to } \\
\text { trypanosomiasis }\end{array}$ & Enock Matovu, & $\begin{array}{l}\text { Makerere University, } \\
\text { Kampala, Uganda }\end{array}$ \\
\hline Type 2 diabetes & WT & $\begin{array}{l}\text { Burden, spectrum, and } \\
\text { etiology of type } 2 \text { diabetes in } \\
\text { Sub-Saharan Africa }\end{array}$ & Ayesha A. Motala & $\begin{array}{l}\text { School of Clinical } \\
\text { Medicine, Nelson R } \\
\text { Mandela (NRMSM) } \\
\text { Campus, University of } \\
\text { KwaZulu -Natal, } \\
\text { Durban, South Africa }\end{array}$ \\
\hline Rheumatic heart disease & WT & $\begin{array}{l}\text { The RHDGen Network: } \\
\text { genetics of rheumatic heart } \\
\text { disease and molecular } \\
\text { epidemiology of } \\
\text { Streptococcus pyogenes } \\
\text { pharyngitis }\end{array}$ & Bongani Mayosi & $\begin{array}{l}\text { University of Cape } \\
\text { Town, South Africa }\end{array}$ \\
\hline
\end{tabular}

H3Africa, Human Heredity and Health in Africa; HIV, human immunodeficiency virus; NHLS, National Health Laboratory Service; NIH, National Institutes of Health; TB, tuberculosis; WT, Wellcome Trust. 